\title{
Pengaruh Latihan PNF Terhadap Peningkatan Daya Tahan Otot Tungkai Pasien Post Stroke Di RSUD Salewangang Maros
}

\author{
Hendrik, Yonathan Ramba, Sri Saadiyah L \\ Jurusan Fisioterapi Politeknik Kesehatan Makassar
}

\begin{abstract}
ABSTRAK
Stroke merupakan penyebab kematian ketiga tersering setelah penyakit jantung coroner dan kanker. prevalensi penduduk Amerika yang terserang stroke adalah $2,6 \%$ atau sekitar 5.839 .000 orang. Prevalensi stroke meningkat seiring dengan bertambahnya usia. Cara untuk meminimalkan kecacatan setelah serangan stroke adalah dengan intervensi fisioterapi yang berupa pemberian latihan-latihan diantaranya pemberian Proprioceptive Neuromuscular Fasilitation (PNF). Penelitian ini bertujuan untuk mengetahui pengaruh pemberian latihan PNF terhadap kemampuan daya tahan otot tungkai pasien post stroke. Penelitian ini adalah pra eksperimen dengan disain pretest-posttest one group design. Populasi adalah pasien post strok yang datang berobat di bagian fisioterapi RSUD Salewangan Maros yang berusia $45-65$ tahun. Sampel penelitian adalah pasien post sroke yang memenuhi syarat mampu berdiri dan berjalan tanpa alat bantu, bukan merupakan kontraindikasi untuk diberikan latihan PNF dan bersedia menjadi responden. Hasil penelitian menunjukkan adanya pengaruh yang signifikan kemampuan daya tahan otot tungkai pasien post stroke sebelum dan setelah diberikan latihan PNF sebanyak 2 kali seminggu selama 4 minggu dengan nilai $p=0,000<0,05$ dengan nilai rata-rata sebelum intervensi sebesar 78,10 $\pm 14,47$ detik dan setelah pemberian PNF diperoleh rata-rata half squat sebesar 141,60 $\pm 21,28$ detik dengan selisih rata-rata sebesar $63,50 \pm 22,09$ detik. Kesimpulan pemberian PNF sebanyak 2 kali seminggu selama 4 minggu dapat mempengaruhi daya tahan otot tungkai pasien post stroke.
\end{abstract}

Kata Kunci: PNF, Daya Tahan Otot, Stroke

\section{PENDAHULUAN}

Stroke merupakan penyebab kematian ketiga tersering setelah penyakit jantung coroner dan kanker (American Heart Associaton, 2004; Bruno-Petrina, 2007; Pinzon, 2009). Stroke juga merupakan penyebab kecacatan nomor satu di dunia . Menurut WHO, lima belas juta orang di dunia terserang stroke setiap tahun, lima juta meninggal, lima juta lainnya menderita kecacatan.

Hasil penelitian BRFSS di Amerika Serikat tahun 2005, prevalensi penduduk Amerika yang terserang stroke adalah 2,6\% atau sekitar 5.839.000 orang. Prevalensi stroke meningkat seiring dengan bertambahnya usia. Pada usia 18 - 44 tahun prevalensinya meningkat sebesar $0,8 \%$ dan pada usia 65 tahun ke atas meningkat $8,1 \%$. Data lain menyebutkan bahwa kematian stroke di Amerika Serikat mencapai lebih dari 160.000 pertahunnya. Sekitar 20\% kasus stroke meninggal pada bulan pertama. Sebesar $70 \%$ penderita pasca stroke memiliki ketidakmampuan (disability) permanen secara okupasional.

Setelah serangan stroke, tonus otot yang normal menghilang. Tanpa pengobatan, penderita akan melakukan kompensasi gerakan dengan menggunakan bagian tubuhnya yang tidak lumpuh sehingga seumur hidunya bagian tubuh yang lumpuh akan tetap lumpuh atau hanya bisa berjalan dengan kaki spastik dan tangan yang cacat. Cara untuk meminimalkan kecacatan setelah serangan stroke adalah dengan intervensi fisioterapi yang berupa pemberian latihan-latihan diantaranya pemberian Proprioceptive Neuromuscular
Fasilitation (PNF). Teknik ini dibrikan dengan maksud melatih pola gerak yang hilang, memperbaiki koordinasi dan meningkatkan kekuatan otot yang lemah. Berdasarkan latar belakang tersebut, maka penulis melakukan penelitian dengan tujuan untuk mengetahui pengaruh pemberian latihan PNF terhadap peningkatan daya tahan otot tungkai pasien post stroke.

\section{METODE PENELITIAN}

Penelitian ini adalah pra eksperimen yang bertujuan untuk mengetahui pengaruh pemberian latihan PNF terhadap peningkatan daya tahan otot tungkai pasien post stroke. Penelitian ini menganalisis kemampuan daya otot sebelum dan sesudah pemberian latihan PNF sehingga disain penelitian adalah pre test - post test one group. Penelitian ini dilaksanakan di poliklinik fisioterapi RSUD Salewangan Maros.

Populasi penelitin adalah pasien post strok yang datang berobat di bagian fisioterapi RSUD Salewangan Maros yang berusia 45 - 65 tahun. Sampel penelitian adalah pasien post sroke yang memenuhi syarat mampu berdiri dan berjalan tanpa alat bantu, bukan merupakan kontraindikasi untuk diberikan latihan PNF dan bersedia menjadi responden.

Data penelitian diperoleh dengan melakukan pengukuran terhadap kemampuan daya tahan otot tungkai pasien post stroke dengan melakukan half squad sebelum dan sehari setelah diberikan latihan PNF dengan frekuensi 2 kali seminggu selama 4 minggu. Data di analisis dengan menggunakan uji paired t-test untuk 
mengetahui perbedaan kemampuan daya tahan otot tungkai post stroke sebelum dan sesudah pemberian PNF.

\section{HASIL DAN PEMBAHASAN}

\section{Analisis Karakteristik Responden}

Hasil analisis menunjukkan bahwa lebih banyak responden yang berusia $58-65$ tahun yaitu 5 orang (50\%) daripada responden berusia $45-50$ tahun yaitu 3 orang $(30 \%)$ dan responden berusia 51 - 57 tahun yaitu 2 orang (20\%). Dilihat dari usia menunjukkan bahwa rata-rata sampel tergolong ke dalam usia tua sehingga hal ini sangat berkaitan dengan proses degenerasi. Menurut William GR et al (1999), Proses degenerasi sangat berkaitan dengan faktor usia, dimana penderita hemiparese post stroke umumnya menyerang usia 55 tahun dan 72 tahun. Usia tersebut memiliki peluang 2 kali terkena stroke yang berakibat pada hemiparese. Adanya penebalan, pengerasan dan terbentuknya trombus pada dinding pembuluh darah merupakan gambaran dari proses degenerasi.

Hasil aqnalisis terhadap jenis kelamin menunjukkan bahwa lebih banyak responden yang berjenis kelamin laki - laki yaitu 6 orang $(60 \%)$ daripada responden berjenis kelamin perempuan yaitu 4 orang (40\%). Menurut American Heart Association(2010), kelompok usia 55 tahun dan 72 tahun umumnya lebih banyak menyerang laki-laki daripada perempuan. Disamping itu, degenerasi pada sistem vaskular lebih banyak terjadi pada laki-laki daripada perempuan. Hal ini berkaitan dengan gaya hidup, dimana umumnya kaum laki-laki memiliki kebiasan merokok, konsumsi alkohol dan konsumsi makanan yang berlebihan serta mobilitas yang rendah (Ann. Thomson, 1991).

\section{Analisis variabel Penelitian}

Variabel yang di ukur dalam penelitian ini adalah daya tahan otot tungkai bawah sebelum dan sesudah pemberian PNF sebanyak 8 kali terapi dengan cara half squat. Untuk melihat kemaknaan hasil terapi terhadap kemampuan half squat, maka di gunakan uji paired t-test. Tes ini bertujuan untuk menguji perbedaan nilai half squat sebelum dan setelah pemberian PNF sebanyak 2 kali seminggu selama 4 minggu dalam satu kelompok sampel yang sama. Hasil analisis diperoleh kemampuan rata-rata half squat sebelum pemberian PNF sebesar 78,10 $\pm 14,47$ detik dan setelah pemberian PNF diperoleh rata-rata half squat sebesar $141,60 \pm 21,28$ detik dengan selisih ratarata sebesar 63,50 $\pm 22,09$ detik. Untuk lebih jelasnya dapat dilihat pada tabel 1 .

Tabel 1 Analisis Kemampuan Half Squat Sebelum dan Sesudah Pemberian Latihan PNF

\begin{tabular}{|c|c|c|c|c|c|}
\hline Waktu Pegukuran & Mean & SD & $\mathrm{n}$ & $\mathrm{t}$ & $\mathrm{P}$ \\
\hline Pre test & 78.1000 & 14.47181 & \multirow{2}{*}{10} & -9.089 & 0,000 \\
\hline Post test & 141.6000 & 21.27701 & & & \\
\hline Selisih Rata-rata & 63.5000 & 22.09198 & & & \\
\hline
\end{tabular}

paired Hasil analisis statistik dengan perbedaan yang signifikan nilai half squat sebelum dan sesudah diberikan latihan PNF dengan nilai $p=0,000<0,05$. Artinya bahwa pemberian latihan PNF sebanyak 2 kali seminggu selama 4 minggu mempunyai pengaruh terhadap kemampuan daya tahan otot tungkai pasien podt stroke.

PNF merupakan intervensi pengobatan yang paling sering digunakan dalam rehabilitasi neurologis. PNF dapat digunakan untuk meningkatkan performa dari tugas/aktivitas fungsional melalui peningkatan strength, fleksibilitas, dan
ROM (Suzanne and Mary, 2007). Salah satu prosedur PNF yang penting adalah pemberian tahanan, dimana tahanan dapat bersifat isotonik (dinamis) dan isometrik. Untuk meningkatkan daya tahan otot (endurance), maka prinsip tahanan yang diberikan adalah tahanan isotonik dengan beban ringan - sedang dan pengulangan gerakan sebanyak mungkin, serta tahanan isometrik dengan durasi yang lama (Kisner and Colby, 2007).

Daya tahan adalah kemampuan untuk melakukan latihan atau aktivitas intensitas rendah, repetitif atau terus menerus dalam jangka waktu yang lama. 
Namun secara khusus daya tahan otot adalah kemampuan otot untuk berkontraksi secara berulang-ulang melawan tahanan atau beban, atau membangkitkan ketegangan (tension) secara terus menerus dan menahan kelelahan dalam jangka waktu yang lama (Kisner and Colby, 2007).

Berdasarkan pembahasan

tersebut menunjukkan bahwa prinsip endurance adalah beban atau tahanan dengan durasi yang lama dan repetisi gerakan yang tinggi. Hal ini yang mendasari pemberian PNF dengan cara half squat. Half squat dilakukan oleh pasien secara statik dan isometrik dalam waktu yang lama. Half Squad dilakukan berulang kali dan dalam durasi waktu yang lama sesuai dengan kemampuan pasien. Jika metode latihan ini dilakukan secara kontinyu dapat menghasilkan perubahan berupa peningkatan daya tahan otot tungkai. Dengan demikian dapat disimpulkan bahwa latihan PNF dapat mempengaruhi kemampuan daya tahan otot tungkai pasien post stroke.

\section{KESIMPULAN DAN SARAN}

Pemberian latihan PNF dapat mempengaruhi kemampuan daya tahan otot tungkai bawah pasien stroke setelah diberikan 2 kali seminggu selama 4 minggu (8 kali terapi).

Di sarankan kepada fisioterapis di rumah sakit atau di lahan praktek sebaiknya menggunakan terapi berupa latihan PNF dalam meningkatkan kemampuan daya tahan otot tungkai pasien post stroke.

\section{KEPUSTAKAAN}

Adler, S., Beckers, D., Buck, M., 2008. PNF in Practice. Third edition. Berlin : Springer Medizin Verlag Heidelberg.

Ann Thomson et.al, 1991. Tidy's Physiotherapy, Twelth Edition, Butterworth Heinemann, Oxford.

Baidya, O.P., Chaudhuri, S., Devi, K.G., 2013. Clinico-Epidemiological Study of Acute Hemoragic Stroke in A

Tertiary Care Hospital of Northeastern State of India. Internatioal Journal of The America Physical Therapi Association: Vol. 66, No. 8.

Cholid Narbuko dan Abu Achmadi, 1991. Metodologi Penelitian. Bina Rupa Aksara. Semarang.

Johnson, B. L., \& Nelson, J. K. (1986), Practical Measurement for Evaluation in Physical Education, (4 ${ }^{\text {th }}$ ed.). Minneapolis, Minnesota: Burgess Publishers Co.

Kisner, C., Colby, L.A.2007. Therapeutic Exercise Foundations And Techniques. Fifth Edition.Philadelphia: F.A. Davis Company.

Klein, D.A., Stone, W.J., Phillips, W.T., Gangi, J., Hartman,S.,2002. PNF Training and Physyical Function in Assisted - Living Older Adults. Journal Of Aging and Physical Activity : Vol. 10, $476-488$.

Suharto, 2012. Penuntun Praktikum Exercises Therapy. Makassar: Poltekkes Kemenkes Makassar.

Suzanne, T. M., Mary, k. 2007 Neurologic Interventions For Physical Therapy. Second Edition. United States of America : Saunders Elsivier.

Tyson, S.F., Hanley, M., Chillala, J., Selley, A., Tallis, R.C., 2006. Balance Disability After stroke. Journal of the American Physical Therapy Association: Vol.86, No.1.

Williams GR, Jiang JG, Matchar DB, et al, 1999. Incidence and occurrence of total (first-ever and recurrent) stroke, BMJ Group. 